\title{
Analisis Fikih Muamalah terhadap Penjaminan Pengembalian Modal Kerja Sama Usaha
}

\author{
Muhamad Rafi Maududi Islam*, Panji Adam Agus Putra, Intan \\ Nurrachmi
}

Prodi Hukum Ekonomi Syariah, Fakultas Syariah, Universitas Islam Bandung, Indonesia.

*rafi070798@gmail.com,panjiadam06@gmail.com, intannurrachmi@unisba.ac.id

\begin{abstract}
The Z Uniform Store in Bandung City cooperates with investors in the school uniform sector, in the contract there is an agreement regarding the risks borne by the mudharib. This study aims to first determine the practice of guaranteeing, business cooperation capital, secondly to find out the fiqh muamalah on the practice of guaranteeing cooperation capital carried out by the Z Uniform Store, Bandung City. The research method used in this thesis is qualitative with a sociological juridical approach, while the type of data for this thesis is field research with data sources taken from the field in the form of interviews and written sources related to the discussion. Data collection techniques are observation, interviews, documentation and literature study. The results show that, firstly, the Uniform Store of $Z$ promises to every investor that the risk is borne by the manager, where the capital will be fully returned to all capital along with the profits if there is a loss, secondly, based on the fiqh muamalah analysis of the practice of guaranteeing. including the mudharabah contract which is false. Based on the theory of tahawwul al-'aqd the contract turns into qordh, but the qordh contract remains invalid because of the division of profits and the merger between credit and buying and selling which is usury.
\end{abstract}

Keywords: Fiqh Muamalat, Dhaman, Cooperation

Abstrak. Toko Seragam Z Kota Bandung melakukan kerja sama usaha dengan para investornya dibidang pakaian seragam sekolah, dalam akadnya terdapat perjanjian mengenai resiko ditanggung seluruhnya oleh mudharib. Penelitian ini bertujuan untuk, pertama mengetahui praktik penjaminan pengembalian modal kerja sama usaha, kedua untuk mengetahui tinjauan fikih muamalah terhadap praktik penjaminan pengembalian modal kerja sama usaha yang dilakukan Toko Seragam Z Kota Bandung. Metode penelitian yang digunakan dalam skripsi ini adalah kualitatif dengan pendekatan yuridis sosiologis, adapun jenis data skripsi ini adalah field research dengan sumber data yang diambil dari lapangan berupa wawancara dan sumber tertulis lain yang berkaitan dengan pembahasan. Teknik pengumpulan data observasi, wawancara, dokumentasi dan studi kepustakaan. Hasil penelitian menunjukan bahwa, pertama Toko Seragam Z menjanjikan kepada setiap investor bahwa resiko ditanggung pengelola, dimana modal akan dikembalikan seutuhnya kepada pemilik modal beserta keuntungan meskipun pengelola mengalami kerugian, kedua berdasarkan analisis fikih muamalah terhadap praktik penjaminan pengembalian modal yang dilakukan Toko Seragam $\mathrm{Z}$ termasuk akad mudharabah yang bathil. Berdasarkan teori tahawwul al-'aqd akad tersebut berubah menjadi qordh, namun akad qordh tersebut tetap bathil karena adanya pembagian keuntuangan dan penggabungan antara pinjaman dan jual beli yang merupakan riba.

Kata Kunci: Fikih Muamalah, Dhaman, Kerja Sama. 


\section{A. Pendahuluan}

Manusia sebagai subjek hukum tidak mungkin dapat hidup di dunia ini sendiri tanpa berhubungan sama sekali dengan manusia lainnya, sebagai makhluk sosial manusia memiliki fitrah yang paling mendasar dalam memenuhi kebutuhan hidupnya. Berkenaan dengan ini Allah memberikan kebebasan kepada manusia untuk mengadakan pertukaran dan perdagangan, hal tersebut memungkinkan manusia dapat berinteraksi dan memenuhi kebutuhan hidupnya. Dalam pengelolaan usaha (perdagangan) dapat dilakukan secara berkelompok atau berserikat guna meningkatkan taraf perekonomian atau keuntungan yang lebih besar, Dalam persfektif muamalah kerja sama dilakukan menggunakan empat akad utama, yaitu mudharabah, musyarakah, muzara'ah, mukhabarah. Pada umumnya akad syirkah yang sering digunakan adalah mudharabah, musyarakah sedangkan pada akad muzara'ah, mukhabarah digunakan dalam sektor pertanian.

Kaitannya dalam penelitian ini bahwa Toko Seragam Sekolah Z yang terletak di Cijerah Kota Bandung, membuka peluang bagi masyarakat yang ingin menginvestasikan uangnya untuk dikelola toko tersebut dengan jangka waktu selama tiga sampai empat bulan, yaitu ketika kenaikan sekolah. Adapun syarat yang digunakan dalam akad tersebut sebagai berikut:

1. Keuntungan investor dibagi berdasarkan besaran dana yang diberikan investor kepada pemilik toko.

2. Jika terjadi kerugian maka keuntungan dan modal harus tetap dikembalikan kepada investor (resiko ditanggung seluruhnya oleh mudharib).

3. Apabila investor membeli barang dari Toko Seragam $\mathrm{Z}$ maka toko memberikan harga grosir (diskon)

Dalam salah satu transaksinya ada investor yang menginvestasikan uangnya sebesar Rp.200.000.000,- (Dua Ratus Juta Rupiah). Maka ketika uang tersebut dikelola bisa untuk membuat 6.300pcs baju ukuran anak SD. Adapun Keuntungan investor untuk setiap baju sebesar Rp.7.000,- (Tujuh Ribu Rupiah) itu artinya keuntungan bagi investor adalah (jumlah pakaian) $\mathrm{x}$ (Rp.7.000), maka keluarlah jumlah Rp.44.100.000,- (Empat Puluh Empat Juta Seratus Ribu Rupiah). Jumlah nominal tersebut ditentukan di awal akad, sifatnya mengikat dan tidak bisa dibatalkan secara mutlak meskipun Toko Seragam Z mengalami kerugian. Selain itu pemilik toko juga menyampaikan semua resiko ditanggung pengelola, oleh karena itu modal investor akan dikembalikan seutuhnya bersamaan dengan jumlah nominal keuntungan meskipun pengelola mengalami kerugian. Proses akad seperti ini diterapkan juga pada investor lain, baik nominalnya kecil ataupun besar.

\section{B. Metodologi Penelitian}

Metode penelitian yang digunakan dalam skripsi ini adalah kualitatif, yaitu suatu kegiatan objektif dalam usaha menemukan dan mengembangkan, serta menguji berdasarkan prinsip atau teori-teori yang disusun secara sistematis melalui proses yang intensif dalam pengembangan generalisasi dengan pendekatan yuridis sosiologis yaitu jenis pendekatan mengenai perilaku masyarakat, perilaku masyarakat yang dikaji adalah prilaku yang timbul akibat berinteraksi dengan sistem norma yang ada, adapun jenis data skripsi ini adalah field research dengan sumber data yang diambil dari lapangan berupa wawancara dan sumber tertulis lain yang berkaitan dengan pembahasan. Teknik pengumpulan data observasi, wawancara, dokumentasi dan studi kepustakaan.

\section{Hasil Penelitian dan Pembahasan}

Dalam penelitian ini menggunakan dua 2 kajian teori sebagai pisau analisis untuk mengkaji yang berkenaan dengan penelitian. Adapun yang dimaksud diantaranya: teori mudharabah dan tahawwul al-aqd. Mudharabah secara bahasa berasal dari kata dharb yang artinya memukul. Pengertian tersebut bermakna proses seseorang menggerakan anggota tubuh untuk menjalankan usahanya. Selain itu mudharabah disebut juga qiradh, yang berasal dari kata al-qardhu yang memiliki makna sepotong, karena pemilik modal mengambil sebagian dari hartanya untuk diperdagangkan dan ia berhak mendapatkan sebagian dari keuntungannya. Menurut Abdullah bin Hammad bin Utsman Al-Khuwaitir bahwa sebutan mudharabah sering digunakan oleh 
masyarakat Irak sedangkan qirad sering digunakan oleh masyarakat Hijaz.

Adapun pengertian mudharabah diantaranya sebagai berikut:

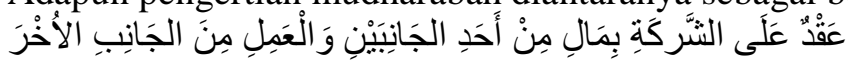

"Adalah akad kerja sama, dimana salah satu pihak menyertakan uang dan pihak lainnya bekerja (mengelola uang tersebut)."

Berdasarkan pengertian mudharabah maka dapat disimpulkan bahwa akad mudharabah adalah akad kerja sama antara dua belah pihak, di mana pihak pertama menyertakan harta dan pihak kedua mengelola harta tersebut. Keuntungan dibagi berdasarkan nisbah yang telah disepakati dan kerugian ditanggung oleh pemilik harta selama kerugian itu murni karena bisnis bukan tindakan wanprestasi dari pengelola.

Secara bahasa tahwwul al-'aqd berasal dari dua suku kata tahwwul dan al-'aqd. Tahwwul bermakna al-intiqal yang artinya berpindah atau bergeser, yaitu bergesernya dari satu tempat ke tempat yang lain sehingga membuat posisinya berubah dari kanan ke kiri. Adapun 'aqd bermakna ikatan yaitu seperti menggabungan kedua ujung tali yang terpisah sehingga menjadi simpul tali yang saling terhubung, Sedangkan secara istilah akad merupakan pertalian (perjanjian) antar ijab (penawaran) dan qabul (persetujuan) yang memenuhi rukun dan syarat pada objek perjanjian sehingga melahirkan suatu akibat hukum. Maka dari itu yang dimaksud tahwwul al-'aqd adalah, apabila suatu akad batal namun didalamnya terdapat rukun-rukun yang memenuhi akad lain maka akad tersebut berpindah kedudukannya menjadi akad lain yang sah.

Maka dari pengertian tesebut penulis menyimpulkan tahwwul al-'aqd adalah akad yang batal secara menyeluruh karena tidak terpenuhi rukun dan syaratnya, namun akad tersebut memiliki rangkaian akad lain, sehingga akad tersebut berubah statusnya menjadi akad baru yang sah dan menimbulkan akibat hukum yang baru.

Hasil menujukan bahwa akad yang dilakukan antara shahibul maal (investor) dengan Junaedi selaku pemilik Toko Seragam Z Kota Bandung merupakan akad mudharabah. Dikatakan akad mudharabah karena salah satu pihak memberikan (menyetorkan) modalnya $100 \%$ dan pihak yang lainnya menjadi pengelola, selain itu perjanjian tersebut termasuk ke dalam jenis akad mudharabah muqayyadah karena pemilik modal mensyaratkan bahwa modal yang ia berikan hanya digunakan untuk kebutuhan usaha toko seragam sekolah, dengan kata lain akad tersebut sifatnya terikat, dimana pengelola hanya bisa menjalankan usahanya sesuai keinginan dari shahibul maal.

Ditinjau dari akad mudharabah terdapat masalah pada pembagian keuntungan diantar para pihak, dimana shahibul maal mendapatkan Rp.7000 perpakaian dan bagi mudharib sisanya (hasil penjualan dikurangi keuntungan dan modal shahibul maal). Karena jika dibagi berdasarkan nominal uang, maka akan menimbulkan ketidak jelasan pembagian keuntungan khususnya bagi pengelola, ini disebabkan karena pengelola mendapatkan keuntungan dari sisa penjualan setelah di kurangi keuntungan dan modal shahibul maal dengan jumlah yang tidak diketahui. Proses berbagi keuntungan seperti ini tidak sah karena pembagian keuntungan sudah ditentukan di awal (keuntungan yang didapat secara pasti) sebagaimana usaha yang menggunakan sistem bunga yang akan menimbulkan keuntungan yang tetap harus tetap diberikan mudharib kepada shahibul maal meskipun mudharib mengalami kerugian.

Selain itu terdapat persyaratan mengenai kerugian yaitu, "Jika terjadi kerugian maka keuntungan dan modal harus tetap dikembalikan kepada investor (resiko ditanggung seluruhnya oleh mudharib)". Maka persyaratan tersebut tidak sah (batal) dengan landasan bahwa akad tersebut merupakan akad amanah, bahwa mudharib adalah wakil dari pemilik harta sehingga kerugian modal di tangan pengelola sama seperti kerugian di tangan pemiliknya. Selain itu praktik yang demikian dapat menghilangkan prinsip keadilan dan berbagi kerugian.

Setelah kita mengetahui akad kerja sama usaha yang dilakukan Toko Seragam Z Kota Bandung merupakan akad kerja sama (mudharabah) yang batal, selanjutnya penulis akan menganalisa akad tersebut menggunakan teori tahawwul al-'aqd untuk menguji sejauh mana akad tersebut mengandung rangkaian akad lain. Dalam transaksi yang mewajibkan debitur mengembalikan uang 100\% kepada kreditur terdapat dalam transaksi Qordh (pinjaman) namun akad tersebut tetap tidak sah karena mengandung unsur riba.

Oleh sebab itu adanya tiga syarat yang ada dalam perjanjian kerjasama usaha Toko 
Seragam Z Kota Bandung akan merusak akad, baik itu akad mudharabah atau qordh (setelah perpindahan akad dari akad kerja sama menuju akad pinjaman). batalnya akad mudharabah karena adanya persyaratan mengenai penjaminan pengembalian modal sehingga akad tersebut berpindah statusnya menjadi akad qordh, namun akad qordh tersebut tetap tidak sah karena adanya unsur riba dari dua persyaratan yang lain.

Maka dapat disimpulkan, berdasarkan pemaparan yang telah diuraikan di atas, bahwa praktik penjaminan pengembalian modal kerja sama usaha yang dilakukan Toko Seragam Z Kota Bandung berdasarkan analisis fikih muamalah terhadap praktik penjaminan pengembalian modal kerja sama usaha tersebut dinyatakan tidak sah.

\section{Kesimpulan}

Dari penjelasan yang telah diuraikan pada pembahasan sebelumnya, berikut kesimpulan bahwa penjaminan pengembalian modal kerja sama usaha yang dilakukan Toko Seragam Z Kota Bandung adalah syarat yang di perjanjikan pengelola kepada setiap investor yang menyimpan dananya di toko tersebut, baik dengan jumlah modal yang besar ataupun kecil, dimana uang modal kerja sama usaha tersebut akan dikembalikan seutuhnya kepada pemilik modal (shahibul maal) beserta keuntungan yang ditentukan di awal akad meskipun Toko Seragam Zmengalami kerugian.

Kemudian berdasarkan analisis fikih muamalah terhadap praktik penjaminan pengembalian modal yang dilakukan Toko Seragam Z Kota Bandung maka dapat disimpulkan bahwa akad tersebut bathil (tidak sah), karena akad mudharabah adalah akad amanah. Terjadinya perjanjian kerja sama usaha disebabkan mudharib menerima modal untuk dikelola atas izin dan untuk kepentingan pemiliknya (shahibul maal), dengan demikian pengelola adalah wakil pemilik modal dalam kewenangan, hal tersebut menyebabkan kerusakan atau kerugian modal di tangan pengelola sama seperti kerusakan atau kerugian di tangan pemiliknya. Maka apabila ada syarat dhaman (penjaminan pengembalian modal), perjanjian tersebut bertentangan dengan prisip dasar, jika suatu akad bertentangan dengan prinsip dasar maka akad tersebut batal. Setelah mengetahui bahwa kerja sama yang dilakukan Toko Seragam Z Kota Bandung batal berdasarkan akad mudharabah, selanjutnya penulis menganalisa akad tersebut menggunakan teori tahawwul al-'aqd untuk menguji sejauh mana akad tersebut mengandung rangkaian akad lain. Pada transaksi yang mewajibkan debitur mengembalikan uang $100 \%$ kepada kreditur terdapat dalam transaksi qordh (pinjaman), oleh sebab berdasarkan teori tahawwul al-'aqd praktik penjaminan pengembalian modal yang dilakukan Toko Seragam Z Kota Bandung termasuk kepada akad qordh (pinjaman) sehingga akan berlaku juga rukun dan syaratnya. (jika investor membeli pakaian seragam sekolah maka harga yang diberikan diberikan adalah harga diskon). maka itu merupakan riba.

\section{Acknowledge}

Penulis mengucapkan terimakasih kepada seluruh pihak yang telah membantu menyelesaikan penelitian ini hingga selesai.

Kepada Dosen Pembimbing, Panji Adam Agus Putra , S.Sy., M.H. dan Ibu Intan Nurrachmi, S.H.I., M.E.Sy.

Kepada Civitas Akademika Fakultas Syariah Universitas Islam Bandung.

Kepada Panitia Spesia Universitas Islam Bandung Tahun 2021.

Kepada Kedua Orang Tua dan Keluarga.

\section{Daftar Pustaka}

[1] Adam, Neneng Nurhasanah dan Panji, Hukum Perbankan Syariah Konsep Dan Regulasi (Jakarta: Sinar Grafika, 2017). hlm. 123.

[2] Adam, Panji, Fikih Muamalah Adabiyah (Bandung: PT Refika Aditama, 2018). hlm. 173.

[3] — Fikih Muamalah Maliyah: Konsep Regulasi Dan Implementasi (Bandung: PT Reflika Aditama, 2019). hlm. 93.

[4] Al-Khuwaitir, Abdullah bin Hamad bin Utsman bin, Al-Mudharabah Fi As-Syar'iyyah AlIslamiyyah Dirasah Muqaranah Baina Madzahib Al-Arb'a (Riyadh: Kunooz Isbilia, 2009). 
hlm. 24.

[5] Junaedi, (Pemilik Toko Seragam Silvi), Cijerah, Kota Bandung, 17 Februari 2021.

[6] Mahmoud, D Haider Jabbar, 'Tahawwul Al-'Aqd Al-Maliyyu Wa Atsaruhu Fi Fiqhi AlIslamiyyati Darasatagu Muqaranah', 4, 186-217

[7] Maruta, Heru, 'Akad Mudharabah,Musyarakah,Dan Murabahah Serta Aplikasinya Dalam Masyarakat', IQTISHADUNA: Jurnal Ilmiah Ekonomi Kita, 5.9 (2016), 80-106

[8] Muhammad Syafii Antonio, Bank Syariah: Dari Teori Ke Implementasi (Depok: Gema Insani, 2017). hlm. 123.

[9] Muhammad, Zaid bin Al-Ramani, 'Aqd Al-Mudarabat Fi Al-Faqih Al-Islamiyati Wa Atsarihi 'Ala Masharifi Wa Buyuti Tamwili IslamiyyatI (Riyadh: Daarul Shamaiy, 2000). hlm. 12.

[10] Purba, Ensu Asmara, 'Analisis Penerapan Strategi Kemitraan Terhadap Kinerja Perusahaan Biro Teknik Listrik (Studi Empiris Pada Hubungan PT. PLN (Persero) Distribusi JatengDIY Area Pelayanan Dan Jaringan Semarang Dengan Perusahaan Biro Teknik Listrik (BTL) Di Wilayah Kerja AP', 17.2 (2008), 197-202 <https://doi.org/10.14710/jbs.17.2.197-202>

[11] Rasyid, Ibrahim, 'At-Tahawwul Fi Al-Asyyai Wa Tasharafati Wa 'Uqudi Wa Atsaruhu Fi Al-Hukmi As-Syariyyati’ (Dar Al-Ulum, 2001). hlm 229. 